\title{
O058. Cluster headache with accompanying migraine-like features
}

\author{
Arens Taga*, Marco Russo, Gian Camillo Manzoni, Paola Torelli \\ From Abstracts from the 1st Joint ANIRCEF-SISC Congress \\ Rome, Italy. 29-31 October 2015
}

\section{Background}

There are limited literature data on migraine-like accompanying features (MLF) in patients with cluster headache $(\mathrm{CH})$. These symptoms are frequently reported by patients [1-3] and may delay $\mathrm{CH}$ diagnosis [4].

The aim of the present study was to investigate the occurrence of migraine symptoms in an Italian case series of $\mathrm{CH}$ patients, and to determine whether these features influence the clinical phenotype of $\mathrm{CH}$.

\section{Methods}

A retrospective cohort study was performed in all consecutive patients referred to the Parma Headache Centre between 1975 and 2013 affected by $\mathrm{CH}$, diagnosed by our team of trained neurologists; the cases were subsequently reviewed applying the ICHD3-beta criteria (785 patients, 569 men and 216 women) [5]. We then identified those patients who reported at least one of the migraine accompanying symptoms (i.e., nausea or vomiting or photophobia and phonophobia); the remaining patients were considered as $\mathrm{CH}$ cases without MLF.

\section{Results}

We identified 362 patients (250 men and 112 women) reporting MLF and 423 patients (319 men and 104 women) without MLF, with a significantly lower M:F ratio in the first group; furthermore these patients had a lower mean age of headache onset $(27.2 \pm 12.1 \mathrm{yrs}$ vs $32.3 \pm 14.3$ yrs).

There were no significant disproportions between the two groups regarding $\mathrm{CH}$ subtype diagnosis (i.e., episodic and chronic diagnosis), the presence of $\mathrm{CH}$ in first-degree relatives and the occurrence of comorbid migraine or of a prior head injury. Smoking habits were significantly less

\footnotetext{
* Correspondence: arens.taga@gmail.com

Parma Headache Centre, Department of Clinical and Experimental Medicine, University of Parma, Parma, Italy
}

was similar.

We found significant differences in $\mathrm{CH}$ time course: attack duration was longer among patients with MLF (89.0 \pm 88.9 minutes vs $76.3 \pm 68.3$ minutes), while there was a lower number of attacks per day $(1.5 \pm 0.9$ vs $2.0 \pm 1.6)$ only among women. We did not find differences in cluster bouts duration and frequency.

Patients with MLF had a higher number of cranial autonomic symptoms ( $3.2 \pm 1.5$ vs $2.8 \pm 1.6)$, with a significantly higher proportion of lacrimation, conjunctival injection, rhinorrhoea, facial sweating and miosis occurring in men only; ptosis was more frequent in both men and women with MLF. Other clinical features such as pain side, pain intensity and restlessness were similarly distributed.

\section{Conclusions}

Our study confirms the high proportion of $\mathrm{CH}$ patients with MLF which is reported in the literature [1-3]. The presence of MLF seems to relate to some peculiar demographic and clinical characteristics of $\mathrm{CH}$ sufferers. Whether these features influence the response to therapy remains to be determined.

Written informed consent to publication was obtained from the patient(s).

\section{Published: 28 September 2015}

\section{References}

Gaul C, Christmann N, Schroder D, Weber R, Shanib H, Diener HC, Holle D: Dincal characteristics and frequency of accompanying me features in episodic and chronic cluster headache. Cephalalgia 2012, 32(7):571-577.

2. Zidverc-Trajkovic J, Podgorac A, Radojicic A, Sternic N: Migraine-like accompanying features in patients with cluster headache. How important are they? Headache 2013, 53:1464-1469.

3. van Vliet JA, Eekers PJE, Ferrari MD, Haan J, for the Dutch RUSSH Study Group: Evaluating the IHS criteria for cluster headache - A comparison between patients meeting all criteria and patients failing one criterion. Cephalalgia 2006, 26:241-245. 
4. van Vliet JA, Eekers PJE, Haan J, Ferrari MD, for the Dutch RUSSH study group: Features involved in the diagnostic delay of cluster headache. $J$ Neurol Neurosurg Psychiatry 2003, 74:1123-1125.

5. Headache Classification Comittee of the International Headache Society: The International Classification of Headache Disorders, 3rd edition (beta version). Cephalalgia 2013, 33:629-808.

doi:10.1186/1129-2377-16-S1-A93

Cite this article as: Taga et al:: O058. Cluster headache with

accompanying migraine-like features. The Journal of Headache and Pain 2015 16(Suppl 1):A93.

\section{Submit your manuscript to a SpringerOpen ${ }^{\circ}$ journal and benefit from:}

- Convenient online submission

- Rigorous peer review

- Immediate publication on acceptance

- Open access: articles freely available online

- High visibility within the field

- Retaining the copyright to your article

Submit your next manuscript at $\gg$ springeropen.com 